\title{
Human Religious Evolution
}

\author{
Ding-Yu Chung \\ Utica, MI, USA \\ Email: dy_chung@yahoo.com
}

Received 1 February 2016; accepted 14 March 2016; published 17 March 2016

Copyright (C) 2016 by author and Scientific Research Publishing Inc.

This work is licensed under the Creative Commons Attribution International License (CC BY).

http://creativecommons.org/licenses/by/4.0/

c) (i) Open Access

\section{Abstract}

This paper posits that human religious evolution is derived from individual vulnerability, the sacred guardian-community-contract, the technological revolutions, and the worldview-sociality model. The paper posits that religion emerged when the vulnerable humans turned to the supernatural as the sacred guardian for help during the harsh Upper Paleolithic Period about forty thousand years ago. The paper posits that religions have evolved with the technological revolutions. The Upper Paleolithic Revolution was produced by religion. After the Agricultural Revolution, the simple sacred guardian in Upper Paleolithic Period was transformed into the sacred guardiancontract as the explicit obligation between the sacred guardian and the human society to maintain the social order in the sacred agricultural-nomadic society. Science, individualism, and pluralism in the Industrial Revolution brought back the secular, resulting in the sacred-secular coexistence in the separate sacred-secular industrial society. The closely interacting information generated by the Information Revolution starts the process unifying the sacred and the secular in the unified interdependent sacred-secular information society. The five periods of human religious evolution based on the technological revolutions are the eusocial secular period started by original Homo sapiens without significant religious practices, the eusocial sacred guardian-community period started from the Upper Paleolithic Revolution, the sacred guardian-community-contract period started by the Agricultural Revolution, the sacred-secular period started by the Industrial Revolution, and the unified interdependent period started by the Information Revolution. This paper posits that the current major religions can be defined by the worldview-sociality model consisting two worldviews (competitive and connective) and three socialities (individualistic, collectivistic, and interdependent as eusocial) derived from the Evolution Equation for the biological evolution based on self-interest, adaptation, and competition. The competitive collectivistic religions are Judaism and Islam. The competitive individualistic religions are Greek individualism and Islam. The connective individualistic-collectivistic religions are Hinduism and Confucianism. The interdependent (eusocial) religions are Buddhism, Daoism, and Christianity.

\section{Keywords}

Religious Evolution, Evolution Equation, Worldview, Sociality, Individual Vulnerability, Upper 
Paleolithic Revolution, Agricultural Revolution, Industrial Revolution, Information Revolution, Secular, Sacred, Judaism, Islam, Christianity, Hinduism, Buddhism, Daoism, Confucianism

\section{Introduction}

The earliest stage of the Robert Bellah's religious evolution [1] is the primitive religion with extensive practice of religious symbols and rituals. This primitive religion started in the Upper Paleolithic Period about forty thousand years ago. In this paper, human religious evolution started from the beginning of original Homo sapiens about two hundred thousand years ago. Human had not had extensive religious practice for about one hundred and sixty thousand years until forty thousand years ago. In other words, the human society in vast majority of the time was secular with insignificant sacred religious practice. The study of human religious evolution starting from the beginning of Homo sapiens to include both the sacred and the secular improves the understanding of human religious evolution.

Human religious evolution improves the understanding of religions as biological evolution improves the understanding of species. Biological evolution explains how a species evolved into several species with different biological structures to adapt to different environments at different times. In the same way, human religious evolution explains how a religion evolved into several religions with different religious structures to adapt to different environments at different times. This paper posits that religion emerged when the vulnerable humans turned to the supernatural as the sacred guardian for help during the harsh Upper Paleolithic Period about forty thousand years ago. This paper posited that the different environments of religions resulted from the technological revolutions at different times. The five periods of human religious evolution based on the technological revolutions are the eusocial secular period started by original Homo sapiens without significant religious practices, the eusocial sacred guardian-community period started from the Upper Paleolithic Revolution, the sacred guardian-community-contract period started by the Agricultural Revolution, the sacred-secular period started by the Industrial Revolution, and the unified interdependent period started by the Information Revolution. This paper posits that the religious structures are based on the worldview-sociality model consisting two worldviews (competitive and connective) and three socialities (individualistic, collectivistic, and interdependent as eusocial) derived from the Evolution Equation for the biological evolution based on self-interest, adaptation, and competition. The competitive collectivistic religions are Judaism and Islam. The competitive individualistic religions are Greek individualism and Islam. The connective individualistic-collectivistic religions are Hinduism and Confucianism. The interdependent (eusocial) religions are Buddhism, Daoism, and Christianity.

Today, the conflicts among religions arise largely from the insufficient understanding of religions. The understanding of various religions derived from human religious evolution provides the base of religious tolerance and peace for both the sacred and the secular. Section 2 describes the Evolution Equation and the worldviewsociality model. The Sections 3, 4, 5, 6, and 7 describe the eusocial secular period, the eusocial sacred guardian-community period, the sacred guardian-community-contract period, the sacred-secular period, and the unified interdependent period, respectively.

\section{The Evolution Equation and the Worldview-Sociality Model}

The biological evolution is based on self-interest, adaptation, and competition. Self-interest motivates individual organism to survive and reproduce. Natural selection in the biological evolution is to select most adaptable member of a species through competition. The biological evolution of individual organism can be expressed as the Evolution Equation in Equation (1).

$$
E=\frac{S A}{C},
$$

where $E, S, A$, and $C$ are the evolution, the self-interest, the adaptation, and the competition values, respectively, and a high $E$ indicates a highly robust evolution. In the Evolution Equation for the biological evolution of social animals, $S$ is the self-interest value described in Equation (2), $A$ is the adaptation value as the number of alliances to build the adaptable infrastructure for food and shelter, and $C$ is the competition value as the number of 
competitors for food and shelter. The infrastructure involves both basic physical and organizational structuresfacilities.

In Equation (1), self-interest is opposite to sociality as the degree of formation of society. There are three different $S$ 's for the three different socialities including individualistic sociality, collectivistic sociality, and interdependent sociality as eusociality as described before [2]. Self-Interest of individual for sociality is expressed as the Self-interest Equation in Equation (2).

$$
S=\frac{1}{r i},
$$

where $S$ is the self-interest value, $r$ is the relatedness coefficient for the degree of relatedness of individuals in a collectivistic sociality, and $i$ is the number of interdependent specialists in an interdependent division of labor in interdependent sociality. The basic relatedness coefficient is the genetic relatedness coefficient for kin sociality [3] [4] as the basic collectivistic sociality. The genetic coefficient is the common share of gene, so $r$ for self is 1 , parent-parent is 0.5 , sibling is 0.5 , half-sibling is 0.25 , nephew-niece is 0.25 , uncle-aunt is 0.25 , grandparent-grandchild is 0.25 , and cousin is 0.125 . For example, the $r$ for a kin social group consisting of a person and the person's child is 1.5. In interdependent sociality which is eusociality [5], each adult is an interdependent specialist focusing in one task without doing other tasks for the division of labor. For eusocial bees, $I$ as the number of the interdependent specialists is 3 , consisting of infertile female worker bee, fertile female queen, and fertile male drone.

The three different socialities are derived from the Self-interest Equation as Equation (2). The highest selfinterest and the lowest degree of sociality is individualistic sociality without permanent social group. For individualistic sociality, $r=d=1$, and $S=1$ for individualistic sociality. The sociality with the lower self-interest and the higher degree of sociality is collectivistic sociality with permanent social group among the individuals which share some common characteristics, such as gene, geography, and culture. Self-interest is extended from merely self to social group among the individuals with some common characteristics. The original collectivistic sociality is kin sociality [3] [4] whose social group is formed by genetically related individuals. For collectivistic sociality, $r>1$, and $i=1$ in the Self-interest Equation.

Another type of sociality is eusociality (interdependent sociality) [5] characterized by the division of labor as in eusocial bees and ants. Homo sapiens are also eusocial [6]. In the division of labor, individuals are interdependent, helping one another. No individual is completely independent or dependent. For example, queen bees reproduce, but must receive care from worker bees that work but must rely on queen bees to reproduce. In interdependent sociality, each adult is anointer dependent specialist focusing in one task without doing other tasks for the division of labor. For eusocial bees, the number of the interdependent specialists is 3, consisting of infertile female worker bee, fertile female queen, and fertile male drone. For the eusocial early human ancestors, the number of the interdependent specialists is 3 , consisting of fertile homemaker-gatherer, infertile homemaker-gatherer, and fertile explorer-hunter. For interdependent sociality, $r>1$ and $I=3$ for eusocial bees and eusocial early human ancestors in the Self-interest Equation. The self-interest in interdependent sociality is the lowest among the three socialities. The low self-interest value is reflected by the short life-times and the self-sacrifices of worker bees and drone bees and the short reproduction (fertility) times for women. Eusociality is the highest level of organization of animal sociality. Being highly cooperative within a group, eusocial species are more plentiful, inhabit more of the habitat, and utilize more of the accessible resources than non-eusocial species.

An evolutionary stable strategy must be based on self-interest, because it is up to individual to reproduce genes. The best evolutionary stable strategy is therefore the highest self-interest. The existence of the low self-interest in the Self-Interest Equation is due to individual vulnerability related to the high difficulty of individual to survive and reproduce independently. Individual vulnerability is overcome by the formation of a social group that helps the vulnerable individuals to survive and reproduce. For examples, the individual vulnerability of children to survive without the help of a social group is the basic reason for collectivistic sociality. The original collectivistic sociality consists of a caring mother and its vulnerable children. The formation of collectivistic sociality is basically due to the vulnerable children. The individual vulnerability of adults to survive and reproduce without the help of a social group is the basic reason for interdependent sociality. In eusocial bees, queen bee is vulnerable because she cannot procure food, and female worker bee is vulnerable because she cannot reproduce. The formation of interdependent sociality is basically due to the vulnerable adults. As a result, groupinterest $G$ is the reciprocal of self-interest, and equal to the individual vulnerability $V$ as the Group-interest Equ- 
ation in Equation (3).

$$
G=\frac{1}{S}=V=r i
$$

Instead of voluntary due to the individual goodness, group-interest is involuntary due to the individual vulnerability. An evolution theory must deal with self-interest, individual vulnerability, and group-interest. For collectivistic sociality and interdependent sociality, the decreased self-interest value $S$ is compensated by increased $A$ with increased number of alliances in the Evolution Equation, so the evolution values for individual organisms are comparable for individualistic sociality, collectivistic sociality, and interdependent sociality.

In the Evolution Equation (Equation (1)), the two strategies to increase the evolution value $E$ with the constant self-interest $S$ are the strategy of the increase of the adaptation value $A$ by increasing the number of alliances to build the adaptable infrastructure for food and shelter and the strategy of the decrease of the competition value $G$ by decreasing the number of competitors for food and shelter. As shown later, connective worldview is the strategy of the increase of number of alliances to build the adaptable infrastructure for food and shelter, while competitive worldview is the strategy of the decrease of the number of competitors for food and shelter. The combination of worldview (competitive and connective) and sociality (individualistic, collectivistic, and interdependent) is the worldview-sociality model. As shown later, interdependent sociality does not have worldview. As a result, the five worldview-sociality types in the worldview-sociality model are competitive individualistic sociality, competitive collectivistic sociality, connective collectivistic sociality, connective collectivistic sociality, and interdependent sociality. As shown later, the competitive collectivistic religions are Judaism and Islam, the competitive individualistic religions are Greek individualism and Islam, the connective individualistic-collectivistic religions are Hinduism and Confucianism, and the interdependent religions are Buddhism, Daoism, and Christianity. As shown later, the worldview-sociality model can also describe economy and politics.

\section{The Eusocial Secular Period}

Human religious evolution of Homo sapiens starts from the emergence of Homo sapiens to the present. The five periods of human religious evolution based on the technological revolutions are the eusocial secular period started by original Homo sapiens, the eusocial sacred guardian-community period started from the Upper Paleolithic Revolution, the sacred guardian-community-contract period started by the Agricultural Revolution, the sacred-secular period started by the Industrial Revolution, and the unified interdependent period started by the Information Revolution.

The eusocial secular period was from the beginning of Homo sapiens around 200,000 years ago to the beginning of the Upper Paleolithic Period about 40,000 year ago. The human society was eusocial and secular. The division of labor in eusociality consisted of fertile homemaker-gatherer mostly for younger women, infertile homemaker-gatherer mostly for older women, and fertile explorer-hunter mostly for men. A good homemaker-gatherer was able to do multitask and navigate through landmarks (food sources) as woman today. A good explorer-gatherer was able to have a good sense of direction (orientation in space) for exploration and strong upper body strength to carry foods and weapons for hunting as man today. There is no evidence for extensive religious practice, so this period was secular with insignificant religious practice.

The eusocial human society may be similar to the modern Bushman in African's Kalahari Desert as described by Marshall Sahlins" "The Original Affluent Society" [7]. It is egalitarian and peaceful. The hunter-gatherer society in small groups (about 20 - 35 people) adjusts its daily needs and desires with what is available to them. The period between childbirths is four to five years by the long prolonged lactation, so the population growth is very slow. Available food is actually fairly adequate for their modest need without population pressure. Without material accumulation, they work only for daily needs, so only the able-bodied work no more than 19 hours only a week, and $40 \%$ of people do not need to work. Without clear property lines, they welcome all visitors. They do not have to permanently stay in one social group. A great deal of evidence suggests that the prehistoric hunter-gatherer society was much less war-like than later peoples. Archaeological studies throughout the world have found hardly any evidence of warfare the prehistoric hunter-gatherer society. Many of the world's cultures have myths that refer to an earlier time. In classical Greece and Rome this was known as the Golden Age; in China it was the Age of Perfect Virtue, in India it was the Krita Yuga (Perfect Age), while the Judeo-Christian tradition has the story of the Garden of Eden [8]. 


\section{The Eusocial Sacred Guardian-Community Period}

The eusocial sacred guardian-community period is the Upper Paleolithic Period from about 40,000 to about 10,000 year ago. The Upper Paleolithic Period was a very difficult period that prompted humans turning to the supernatural for help. During the Upper Paleolithic Period, a number of sudden temperature drops reduced significantly the area for forest in Europe and Asia. The reduction of forest reduced the food supply, usable timber, and other non-food materials. During the harsh Upper Paleolithic Period, the human society was preoccupied with fertility and vitality for women and men, respectively. The imaginary female figurines and cave paintings appeared during the period. In most cases, the imaginary exaggerated and distorted female figurines were miniature sculptures of well-rounded female nudes with an overemphasis of the fleshy parts of the body (buttocks, stomach and chest). The sexual accent on the female breasts and the posterior are assumed by many to connote signs of fertility. The head and arms are mostly absent with the stress on the middle of the torso. Thighs tend to be exaggerated tapering into smaller legs. The head has no face. According to Alan F. Dixson and Barnaby J. Dixson, these female figurines symbolized and brought the hope for a well-nourished and fertile community to change the fate of facing grim winters and a scarce food supply [9]. In the imaginary cave paints, the animals were mystic large strong animals or mystic animals with horns that symbolized maturation and strength. According to David Lewis-Williams [10], the imaginary cave paintings involved hallucinatory or trance states by drugs or repetitive rhyme. The mystic animal pictures were conceived during the trance states. The mystic powerful animal cave paintings were presented as evidence of spirit journeys previously undertaken. These cave paintings symbolized and brought the hope for a vital and powerful community to change the fate of facing grim winters and a scarce food supply.

The female figurines and the cave painting represented the supernatural in terms of fertility for women and vitality for men, respectively. The concept of the supernatural at the time of the Upper Paleolithic Period was considerably different from the current concept of the supernatural. At the time of the Upper Paleolithic Period, the supernatural was the immanent supernatural that appeared everywhere as a part of all objects in the world. (The transcendental supernatural was developed later.) Anything unexplained or unusual was attributed to the supernatural. Everyone and everything was able equally to become an avatar, the incarnation of the supernatural. The symbols for the immanent supernatural were typically the exaggerated and distorted representation of the real natural objects to represent the unexplained and unusual characteristics of the immanent supernatural. During the harsh Upper Paleolithic Period, the vulnerable humans sought the help from the immanent supernatural as the sacred guardian by ways of the female figurines and the cave paintings.

During the Upper Paleolithic Period, there was the increasingly sharing of the female figurines and the cave paintings among different social groups. The enormous distribution of these female figurines implied a ritualistic exchange system with the figurines playing a central role in intergroup relations [11], resulting in the intergroup sacred guardian-community of female figurines. Practicing alternate states of the mind also became community rituals among different social groups, often led by shaman inside or outside of caves. The practicing of the alternate state of mind together promoted unity among different social groups, resulting in the intergroup sacred guardian-community of cave paintings. The sharing of the religious symbols brought about the sharing of survival information and resource among different social groups. The sharing actually improved the fertility and vitality of the groups involved, resulting in the validation of the power of the religious symbols. The result was the rise of the female figurine and cave painting religion. People spent much more energy and time to develop and make such religious symbols for the sacred guardian, resulting in the Upper Paleolithic Revolution [12] with the rapid development and spread in religious art and the involved skills. Similar to the Industrial and Neolithic Revolutions, the Upper Paleolithic Revolution during the Upper Paleolithic period represents a short time span when numerous inventions appeared and cultural changes occurred. The revolution comprised new religions, technologies, hunting techniques, human burials, and artistic work. The human society became more cooperative especially in intergroup cooperation beneficial to the survival of humans during this harsh period. The sacred guardian as religion became a well-established tradition, spreading to all human societies in the world. The sacred guardian as religion has been ubiquitous in all human societies.

The belief in the sacred guardian that is the belief in turning to the sacred guardian for help is the belief system of the dependence on the sacred guardian. A consequence of the human dependence on the sacred guardian is the domestication of humans by the sacred guardian in the same way as the domestication of dogs that heavily depend on humans. A consequence of domestication is the shrinking brain. The brain size of Homo species 
starts from about $600 \mathrm{~cm}^{3}$ in Homo habilis up to about $1600 \mathrm{~cm}^{3}$ in Neanderthals and Cro-Magnon people. Since then, the average human brain size has been shrinking over the past 30,000 years about $10 \%$ in size from around $1550 \mathrm{~cm}^{3}$ to around $1440 \mathrm{~cm}^{3}$ in males, and from around $1500 \mathrm{~cm}^{3}$ to around $1240 \mathrm{~cm}^{3}$ in females [13]. This has happened everywhere in the world. One model to explain the brain shrinkage is the domesticated brain [14] [15]. Some 30 domesticated animals have lost brain volume, typically a 10 to 15 percent reduction compared with their wild progenitors. The brain shrinkage can be done by regulatory genes that determine the timing of the brain development, so the brain development is stopped before the fully independent adult stage to retain some characteristics of docile and dependent juvenile characteristics as the requirement for the domestication of animals with the reduction of strong-will and independent characteristics. Wolves are more persistent than dogs evolved from wolves in solving simple problems like how to open a box. Dogs are more readily give up in order to using humans as tools to solve problems for them in the same way that juvenile wolves are more readily to give up in order using their parents as tools to solve problems for them.

The sacred guardian has domesticated humans since the harsh Upper Paleolithic Period from about 40,000 years ago. Humans have turned to the sacred guardian for strength and good fortune during the difficult time in the same way as dogs turning to humans for help. In this way, the sacred guardian has domesticated humans as humans have domesticated dogs. The conformity to the belief system of the dependence on the sacred guardianfavors the docile and dependent adults over strong-will (stiff-necked) and independent adults in the same way that the domestication of animals favors docile and dependent animals over strong-will and independent animals. The marginalization of strong-will and independent adults reduces the reproduction of strong-will and independent people, and enhances the reproduction of docile and dependent adults who have the shrinking brains in the same way that the domestication of animals reduces the reproduction of strong-will and independent animals, and enhances the reproduction of docile and dependent animals that have the shrinking brains. The beneficial Upper Paleolithic Revolution was a result of the sacred guardian as religion, while the shrinking brain is the side-effect of the domestication by the sacred guardian. The human society during the eusocial sacred guardian-community period continued to be eusocial with the extended division of labor by the addition of religious specialists who specialized in religious practices. The sacred eusocial society continued to be egalitarian and peaceful. Neanderthals nearly died out about 40,000 years ago [16], and the interbreeding between Neanderthals and Homo sapiens occurred about 50,000 to 60,000 years ago, so Neanderthals did not have the chance to develop the Upper Paleolithic Revolution.

\section{The Sacred Guardian-Community-Contract Period}

The sacred guardian-community-contract period is from the Agricultural Revolution (Neolithic Revolution) about 10,000 year ago to the beginning of the Industrial Revolution about 250 year ago. The Neolithic Revolution as the transition from nomadic hunting and gathering to the cultivated crops and domesticated animals for their subsistence was first adopted by various independent prehistoric human societies about 10,000 years ago. The Neolithic Revolution may be caused by climatic change from the retreat of the glaciers at the end of the last Ice Age at about 12,000BC. These climatic shifts prompted the migration of many big game animals to new pasturelands in north areas. They left a dwindling supply of game for human hunters in areas such as the Middle East. Climatic shifts also led to changes in the distribution and growing patterns of wild grains and other crops on which hunters and gatherers depended. These changes forced people to systematic cultivation of plants and domestication of animals as the supplement for the undependable source of food by gathering and hunting. As cultivated crops and domesticated animals improved, people depended on cultivated crops and domesticated animals as the main food source, resulting in the agricultural-nomadic society.

The method involved plow and draft animals drastically improved the productivity. Plowing maintained the fertility of the soil by turning topsoil. Agriculture could support population increases by more intensive use of the same piece of land. Farmers grew crops for sale rather than crops grown only for household use. Market became an important part of society. Surplus food production brought about non-food-producing professionals, such as religious or ruling elites. Large cities emerged. It was the start of civilization whose original meaning relates to being a citizen, who was governed by the law of one's city, town or community. Plowing by draft animals allowed large farm far away from home. Plow technology, which required more upper body strength and allowed large farm far away from home, did not allowed women to participate in plowing the fields and rearing children at the same time. They still did much of the processing and preserving of food, but their contribution to 
the household was not as valued as the work that men did because they did not contribute economically by selling products. Gender inequality was severe in the agricultural society.

Civilization was an irreversible process, because the social group of large population caused by civilization had to be supported by agriculture. The reverse to the pre-agricultural-nomadic society would have led to mass starvation. The agricultural society required to stay in the same place, so it was more prone to the periodic local natural disaster, unlike the hunter-gatherer society that was free to move away from local natural disaster. The constant population pressure and the periodic natural disasters caused the deficient resource and security. The hunter-gatherers were averaged 6 inches taller than agricultural peoples up to 100 years ago. Today, we are now as tall as we once were. The life expectancy in the agricultural-nomadic society was actually shorter than in the hunter-gatherer society.

Unlike the prehistoric eusocial hunter-gatherer society without accumulated personal wealth, the agricultural-nomadic society involved accumulated personal wealth. The increase in personal wealth accumulation increases the self-interest value $S$ in the Self-interest Equation (Equation (2)). Interdependent sociality has the lowest self-interest value. The increase in personal wealth accumulation that increases the self-interest value transformed interdependent sociality into collectivistic sociality in the Self-interest Equation. The further increase in personal wealth accumulation resulted in individualistic sociality. Such increasing personal wealth accumulation inevitably generated severe conflicts. A sign of severe conflicts in the agricultural-nomadic society was warfare. Cultural anthropologist, Raymond C. Kelly [17] believes that warfare originated very late in human evolution. Archaeological evidence points to a commencement of warfare that postdates the development of agriculture. This strongly implies that earlier hunter-gatherer societies were warless and that the Paleolithic was a time of universal peace. One example is Japan where the agricultural society was established very late. In Japan, intensive agriculture came in with migrants from the mainland about 2300 years ago. Archaeologists have excavated some 5000 skeletons that predate the intrusion, and of those only ten show signs of violent death. In contrast, out of about 1000 post-migration excavated skeletons, more than a hundred show such signs. The deviation from the human innate goodness of the prehistoric interdependent sociality has been described by various religions. In the Bible, the deviation represents the exit from the Garden of Eden. In the Bible, the Garden of Eden symbolizes the interdependent sociality. The forbidden fruit symbolizes civilization. The eating of the forbidden fruit by Adam and Eve resulted in the death, as commanded by God, “...but you must not eat from the tree of the knowledge of good and evil, for when you eat of it you will surely die (Genesis 2:7). "For as in Adam, all die." (1 Corinthians 15:22)". "for all have sinned and fall short of the glory of God. (Romans 3:23)." The deviation from the original goodness represents the spiritual death after civilization.

In the prehistoric society, the implicit eusocial instincts were good enough to keep social order. To avoid severe conflicts, the maintenance of social order in the agricultural-nomadic society required explicit moral codes and laws as described in Dao De Jing. For Daoism, the emergence of the civilized society is the deviation from the Great Way in the prehistoric time.

Therefore, when the Great Way is rejected, it is then that we have the virtues of humanity and righteousness. When knowledge and wisdom appear, it is then that there is great hypocrisy. When the six relations are not in harmony, it is then that we have filial piety and compassion. When the country is in chaos and confusion, it is then that there are virtuous officials. (Chapter 18, Dao De Jing)

As described in Chapter 18, Dao De Jing, to keep social order in the agricultural-nomadic society required explicit knowledge, wisdom, filial piety, compassion, and virtuous officials. As a result, after the Agricultural Revolution, the simple sacred guardian in Upper Paleolithic Period was transformed into the sacred guardian-contract as the explicit obligation between the sacred guardian and the human society to maintain the social order in the agricultural-nomadic society. To have the supernatural as the benevolent sacred guardian, the social group and individuals must fulfill the obligations in the sacred contract as written in the religious sacred texts. The severe conflicts in the agricultural-nomadic society destroyed interdependent relationship. Without interdependent relationship, the agricultural-nomadic society became individualistic sociality or collectivistic sociality. The sacred contracts are the individualistic and collectivistic sacred contracts.

The additional factor in human religious evolution is "worldview" based on territorial boundary. For social animals normally, a clear territorial boundary exists, so there is clear distinction between "ingroup" and "outgroup”. In ingroup, individuals share similar interests and attitudes, and produce instinctive feeling of ingroup favoritism as solidarity, community, and exclusivity [18]. Individuals in outgroup outside one's own group are 
different in interests and attitudes, and produce instinctive feeling of outgroup derogation as inferiority and alienation. Morality is defined as proper behavior. Morality toward ingroup is opposite of morality toward outgroup. Group morality consists of instinctive ingroup morality and instinctive outgroup morality [19]. Ingroup morality is cooperative connection derived from instinctive ingroup favoritism. Outgroup morality is zero-sum aggressive competition derived from mutual outgroup derogation among social groups. According to evolutionary psychologists, this discrimination between connective ingroup morality and competitive outgroup morality has evolved because it enhances group survival in terms of instinctive cooperative connection toward ingroup and instinctive aggressive competition towards outgroup [20]. Such attitudes toward ingroup and outgroup are instinctive, appearing even in babies at few months old. As shown in the Infant Cognition Center at Yale University [21], babies prefer the objects (such as dolls) as ingroup objects that have similarities with the babies rather than the objects as outgroup objects that do not have similarities with the babies. Babies also prefer the objects with helpful behavior to the objects with bully behavior. However, babies prefer the doll that bullies another doll that is not like the babies. In other words, even though babies dislike individuals who harm other individuals, babies prefer individuals who harm outgroup individuals that are not like the babies. The zero-sum competitive attitude toward outgroup is instinctive.

In the Evolution Equation (Equation (1)), the two strategies to increase the evolution value $E$ with the constant self-interest are the strategy of the increase of the adaptation value by increasing the number of alliances to build the adaptable infrastructure for food and shelter and the strategy of the decrease of the competition value by decreasing the number of competitors for food and shelter. The attitude toward ingroup corresponds to the strategy of the increase of the adaptation value by increasing the number of alliances in ingroup to build the adaptable infrastructure for food and shelter, and the attitude toward outgroup corresponds to the strategy of the decrease of the competition value by decreasing the number of competitors in outgroup for food and shelter.

In the pre-civilized human society, there was a clear territorial boundary existed between ingroup and outgroup for the hunter-gatherer society. About 10,000 years ago, the agricultural-nomadic revolution (the Neolithic Revolution) occurred to replace the hunter-gatherer society with the agricultural-nomadic society. About 5000 years ago, urban societies developed, resulting in the first civilizations in agricultural society with city states as the basic political units. Meanwhile, large clans were developed in nomadic society with clans as the basic political units. Agricultural society started from large rivers, such as Mesopotamia between Tigris and Euphrates Rivers, Egypt along Nile River, China along Yellow River, and India along Indus River. Nomadic society started from arid land and grassland outside of the river valleys. There were clear borders between ingroup and outgroup among the basic political units. People were clearly loyal to their city states or clans. During this period, city-states/clans became highly fortified by various local religions, local governmental structures, and local physical structures. The fortified city-states/clans did not allow easy informal combination among city-states or clans.

The advance of technology and the increase in population and wealth increased the interactions among multiple city-states/clans, resulting in the continuous merges and splits of city-states/clans that destroyed clear boundaries. Eventually, an invisible domain consisting of multiple city-states/clans was perceived as the world without clear boundaries, and "worldview" was developed as how individuals to view the world that had no clear territorial boundaries among the multiple city-states/clans. If the world is viewed as ingroup consisting of connecting multiple city-states/clans, the worldview is connective worldview. If the world is viewed as outgroup consisting of zero-sum competing multiple city-states/clans, the worldview is competitive worldview. In the Evolution Equation (Equation (1)), the two strategies to increase the evolution value with the constant self-interest are the strategy of the increase of the adaptation value by increasing the number of alliances to build the adaptable infrastructure for food and shelter and the strategy of the decrease of the competition value by decreasing the number of competitors for food and shelter. Connective worldview corresponds to the strategy of the increase of the adaptation value by increasing the number of alliances in the world as ingroup to build the adaptable infrastructure for food and shelter, and competitive worldview corresponds to the strategy of the decrease of the competition value by decreasing the number of competitors in the world as outgroup for food and shelter.

Agricultural society and nomadic society developed different worldviews. In sedentary agricultural society, the main economic growth model was the economic gain in agricultural products from the investment in the complex infrastructures, such as market, transportation, and irrigation. The infrastructure involves both basic 
physical and organizational structures-facilities. Agricultural society was motivated to form alliances in order to connect the infrastructures among city-states. As a result, agricultural society developed connective worldview to view the world as connective city-states. In mobile nomadic society without a fixed settlement for the complex infrastructures, the main economic growth model was the economic gain from the plundering of properties by conquest. The plundering of properties by conquest in nomadic society generated the competitive world, so nomadic society developed competitive worldview to view the world consisting of competitive clans.

The history of worldview is the history of the West originated from the Middle East and Greece and the East originated from India and China. Nomadic society by itself did not have enough people and natural resource to establish great civilization, but in the West, the nomadic society conquered the agricultural society, and established competitive worldview in the conquered agricultural society. The two groups of nomads in the West were the Semitic nomads and the Eurasian nomads. In the West, the agricultural Middle Kingdom (2120-1780BC) of Egypt was conquered by a Semitic nomad, Hyksos. The agricultural Sumer was conquered by Akkad related to Semitic nomad outside of Sumer. After the conquests by the nomads, both Egypt (the New Kingdom 15501069BC) and Mesopotamia (the Akkadian Empire 2350-2150BC) turned into aggressive imperialistic empires with competitive worldview. (The Middle Kingdom and Sumer were not imperialistic.) Afterward, competitive worldview has been firmly established in the West. In agricultural Indus Valley and Yellow River Valley, the connective worldview of agricultural society reversed or resisted competitive worldview of the invading nomads. The East has not developed permanently aggressive imperialistic empires with competitive worldview as neither China nor India has reached beyond Asia. The competitive West pursues global military hegemony by defeating competitors in the perceived competitive world, while the connective East pursues regional community to build the adaptable infrastructure for clothing, food, shelter, and transportation in the perceived connective world as described in the Evolution Equation (Equation (1)).

Instinctive connective worldview of the East and instinctive competitive worldview of the West are also manifested as instinctive connective cognition of the East and instinctive discrete cognition of the West [22]. With connective worldview, the Easterners see a world of continuous and connected objects with relationships, while with competitive worldview, the Westerners see a world of discrete and unconnected objects in categories based on similarity and difference. Westerners pay attention to the focal object separated from its surrounding based on discrete cognition, while Easterners attend more broadly— to the overall surroundings and to the relations between the object and the field.

The Agricultural Revolution destroyed interdependent sociality (eusociality), and converted it into individualistic sociality and collectivistic sociality. The worldview-sociality model as the combination of worldview and sociality produces competitive individualistic sociality, competitive collectivistic sociality, connective individualistic sociality, and connective collectivistic sociality. Connective worldview and competitive worldview are opposite to each other in terms of morality. What consider as moral in one worldview is immoral in another worldview. The preferred behavior in one worldview is the forbidden behavior in another worldview.

In connective worldview morality, morality is connective described in highly favorable terms, and immorality is competitive described in highly unfavorable terms. For connective individualistic sociality, the moral individualistic behavior is connective as reciprocity where both individuals cooperate with each other. The immoral individualistic behavior is competitive as egotism where one individual divides oneself from other individuals. For connective collectivistic sociality, the moral collectivistic behavior is connective as cohesive relationship to keep multiple groups cohesive. The immoral connective collectivistic behavior is competitive as divisive bigotry to look down certain groups of people in multiple groups. In competitive worldview morality, morality is competitive described in highly favorable terms, and immorality is connective described in highly unfavorable terms. The moral competitive individualistic behavior is competitive as freedom to compete. The immoral competitive individualistic behavior is connective as restriction of the freedom to compete. For competitive collectivistic sociality, the moral competitive collectivistic sociality is competitive as supremacy of the group over multiple groups. The immoral competitive collectivistic behavior is connective as inferiority of the group below multiple groups. Competitive worldview considers moral reciprocity in connective worldview as immoral restriction to interfere individualistic freedom, and considers moral cohesive relationship in connective worldview as immoral inferiority to accommodate outside groups. Connective worldview considers moral freedom in competitive worldview as immoral egotism to be inconsiderate of other people, and considers moral supremacy in competitive worldview as immoral divisive bigotry. The two opposite worldviews are summarized as Table 1. 
Table 1. Two opposite worldviews.

\begin{tabular}{|c|c|c|c|}
\hline & & Connective worldview & Competitive worldview \\
\hline World & & View the world as ingroup & View the world as outgroup \\
\hline Historical origin & & $\begin{array}{l}\text { Sedentary agricultural society } \\
\text { The east originated from } \\
\text { India and China }\end{array}$ & $\begin{array}{l}\text { Mobile nomadic society } \\
\text { The west originated from the } \\
\text { Middle East and Greece }\end{array}$ \\
\hline Economic growth model & & Infrastructure & Conquest \\
\hline \multirow[t]{2}{*}{ Individualistic Sociality } & Morality & Reciprocity & Freedom \\
\hline & Immorality & Egotism & Restriction \\
\hline \multirow[t]{2}{*}{ Collectivistic Sociality } & Morality & Cohesive relationship & Supremacy \\
\hline & Immorality & Divisive bigotry & Inferiority \\
\hline
\end{tabular}

The three most important competitive religions in the West are Judaism from Israel, Greek individualism from Greece, and Islam from Arab. Greek individualism includes individualistic Greek mythology, politics, and science. The Israel tribe was herd-nomadic tribe, Greece with the strong influence from Athenian culture was trade-nomadic society for trading olive oil, and Arab was both herd- and trade-nomadic tribe. Herd-nomadic society required strong collectivistic government to protect a tribe, so herd-nomadic society developed competitive collectivistic sociality. The morality for competitive collectivistic sociality is supremacy. Judaism unified herdnomadic clans. Trade-nomadic society developed trading cities to trade goods from different places. In a trading city of trade-nomadic society, a high degree of freedom was required among individual traders from many different cultural and political backgrounds to trade and to exchange information, so trade-nomadic society developed competitive individualistic sociality. The morality for competitive individualistic sociality is freedom. Greek individualism unified trading city states. Arab was the mixture of both herd-nomadic society and tradenomadic society, so the worldview of Islam originated from Arab is the combination competitive individualistic sociality for diversity and collectivistic worldview for supremacy. Islam unified both herd-nomadic and tradenomadic clans.

Israelite tribe emerged during the chaotic period in the Canaanite city-states when the clear territorial boundaries no longer existed. Being the outsiders outside of the Canaanite city-states, Israelites developed competitive worldview for the perceived competitive world without clear territorial boundaries. Nomadic Israelite tribe established competitive collectivistic Judaism. Collectivistic sociality in Judaism is manifested as sharing, equality, and strong group identity. The moral competitive collectivistic behavior is supremacy of group, and the immoral behavior is inferiority of group. In Judaism, worshipping supreme Yahweh is moral, while worshipping foreign gods who are inferior is immoral in the perceived highly competitive world from competitive worldview. The other tribes in the area did not develop such distinctively competitive worldview. In the inevitable endless competition between the supreme and the inferior internally and externally in the competitive world, the key for the survival of Judaism is the prophecy of the end time when the supreme as the sacred savior (messiah) will eventually and dramatically triumph over the inferior as shown in all surviving competitive collectivistic religions. The prophecy of the savior in the end time provides the hope for the eventual peace to change the fate of facing grim defeat and suffering.

Islam adopted the same competitive worldview. Mecca, the origin of Islam, was a trading city surrounded by nomadic tribes, so Islam is a competitive collectivistic-individualistic religion. Islam in the early period was much more individualistic than Islam in the late period. In Greek mythology, gods are individualistic and competitive. Heroes are the highest individualistic achievers overcoming all obstacles in competition. Science and mathematics were originally the individualistic intellectual pursuits in Greece. The moral competitive individualistic behavior is freedom, and the immoral behavior is restriction. In Greece, Athens established the earliest democracy which provided individuals the freedom to compete politically.

In China, India, and the Far East for the East, the worldview is connective worldview with connective morality. The rulers in China and India were mostly agricultural people or nomads converted into agricultural people. Connective morality based on reciprocal relationship and cohesive relationship was suitable to a sedentary and peaceful agricultural society. In agricultural-nomadic India, Hinduism was transformed from the competitive religion in the Vedic Period into the connective religion after the Vedic Period. In agricultural China, Confucian- 
ism is a connective religion. The morality for connective religion includes reciprocity and cohesive relationship, while the immorality for connective religion includes egotism and divisive bigotry. In Indian connective culture, all religions except the religions from the West have sooner or later merged. All gods somehow are related through marriages, relatives, functions, or reincarnations. Without the objections from the West, Indian culture could have easily linked Abraham, Moses, Jesus, and Mohamad in a reincarnation relationship. In Chinese connective culture, people practice different religions at different occasions. A young person with heavy responsibilities in government and family practices Confucianism. A retired person likely practices Daoism and Buddhism. They practice religions as ways of life, because they like such ways of life, and think such ways of life are beneficial without directly invoking the names of personal gods. In important occasions, turning points, and difficult times, they worship gods and ancestors invoking the names of personal gods and ancestors. They do not feel any contradictions by practicing different religions at different occasions, because the Eastern worldview is connective. By practicing different religions at different occasions, Chinese culture does not have a great need to merge religions as in Indian culture. In the Western competitive worldview, such Indian and Chinese practices of cooperation in religions are unthinkable and blasphemous. In the perceived connective world from connective worldview, the connective religions do not have the prophecy of the end time.

The formations of individualistic sociality and collectivistic sociality in the agricultural-nomadic society generated a backlash to return to interdependent sociality (eusociality) practiced in the eusocial secular period or the eusocial sacred guardian-community period. The interdependent sociality without large political state was formed as the interdependent religions (Christianity, Buddhism, and Daoism) to practice the interdependent ways of life in the eusocial society before civilization (The eusociality without large political state consisting of multiple groups does not have worldview.). Bypassing the sacred contract as the laws of the Old Testament, Christianity practices the interdependent ways of life in the eusocial sacred guardian-community period manifested as the sacred eusocial kingdom of God based on love and the interdependence among the followers of Jesus Christ. Bypassing both the sacred contract as the complex Vedic laws and the sacred guardians as various deities, Buddhism practices the interdependent ways of life in the eusocial secular period manifested as the secular eusocial sanctuary based on compassion, meditation, impermanence, and interdependence. Bypassing moral codes and various deities, Daoism practices the interdependent ways of life in the eusocial secular period manifested as the secular eusocial small remote state based on yin-yang interdependence, natural intuition, and the unity with the nature.

Buddhism and Daoism were originally secular, and became sacred later. However, they can still be practiced as the secular religions without invoking sacred names. One of the common practices is the mediations based on simple perceptions here and now without abstraction, permanence, and independence. The common simple perceptions in meditations include the perceptions of breath and simple words (mantras). The purpose of the meditations is the minimization of self, inducing the minimization of self-interest. The minimization of self-interest results in the return to interdependent sociality with the lowest self-interest value in the Self-interest Equation (Equation (2)).

\section{The Sacred-Secular Period}

The sacred-secular period was started by the Industrial Revolution about 300 year ago. The foundation of the Industrial Revolution is the Renaissance that provided science for the foundation of industrial technology and individualism for the foundation of capitalism in the Industrial Revolution. Before the Renaissance starting from the 14th century, while the restriction of freedom kept Christian kingdoms in the Dark Age, the competitive individualistic aspect of the competitive individualistic-collectivistic Islam allowed the Muslim Empires to prosperous and to make tremendous progress in science, mathematics, technology, and Greek individualistic philosophy. The Renaissance in the Christian kingdoms was started essentially by learning the Muslim individualistic culture containing science and individualism.

Before the Renaissance, the Christian church essentially promoted the competitive collectivistic religion with the sacred collectivistic contract established by the church. During the Renaissance, individualism challenged the sacred collectivistic contract established by the church, and returned the Christian church back to the direct relationship with the sacred guardian, Jesus Christ, bypassing the sacred collectivistic contract established by the church. The direct relationship with the sacred guardian, Jesus Christ, became the base for the Protestant church. Individualism, science, and rationalism in the Enlightenment of the 18th Century championed the destruction of 
all barriers to human freedom and autonomy. In France, the revolution moved to eliminate religion from society all together and based its values on secular humanism without the involvement of God. The explosion in scientific discovery in the $19^{\text {th }}$ century catapulted human invention and innovation onward into the Industrial Revolution. Science became the new faith of the masses.

The Industrial Revolution replaced an economy based on manual labor by one dominated by machinery. The dramatic increase in productivity lifted most people from the poverty in the agricultural-nomadic society. The Industrial Revolution started in the mid-18th century and early 19th century in Britain and spread throughout the world. The Industrial Revolution generated the modern pluralism which is derived from communication, transportation, and migration. Before the Industrial Revolution, most people lived in isolated social group, so the major traditional religions were able to overcome pluralism by maintaining one religion or one system of religions in one isolated social group. The modern pluralism by advanced modern communication, transportation, and migration has broken down the barriers among isolated social groups. The old major traditional religions that worked well in isolated social group faced serious challenges from this modern pluralism without barriers among isolated social groups.

The Industrial Revolution has improved human living condition tremendously. At the same time, individualism, science, and pluralism have challenged traditional religions in the industrial West. The industrial West includes the highly developed industrial countries in Europe and North America. The industrial West has been the dominant force in science, technology, politics, economy, and religion. People in the industrial West remain religious as long as people feel insecure enough in the secular world to have the need for the sacred guardian and the sacred contract. In the European countries of the industrial West, people feel secure enough in the secular world, so the sacred guardian and the sacred contract are largely replaced by the secular science and the secular ideology in secular politics and economy. In the industrial West, the secular competitive individualistic economy is capitalism, the secular competitive collectivistic economy is socialism, the secular competitive individualistic politics is liberal democracy, and the secular competitive collectivistic politics is ideological authoritarianism, such as communism. Such secular ideologies are even more developed and systematized than the sacred contracts. Meanwhile, the industrial East has not been the dominant force in science, technology, politics, economy, and religion, but it also develops its own secular ideologies based on connective worldview. The secular economy based on connective worldview is connective economy as practiced in Japanese economy including zaibatsu (connective collectivistic economy) and keiretsu (connective individualistic economy). The secular politics based on connective worldview is meritocracy as practiced in China without competitive partisan politics. Meritocracy includes meritocratic selection for connective individualistic politics and consensual politics for connective collectivistic politics. The worldview-sociality model is listed in Table 2 for various religions and secular ideologies.

As the interdependent religions, Buddhism and Daoism were originally secular, and became sacred later. However, they can still be practiced as the secular interdependent way of life to return back the primitive eusocial secular society which was in existence for about 160,000 years 40,000 year ago. As a result, it is possible to live a completely secular life based on secular technology, science, politics, economy, and religion everywhere in the world.

Table 2. The worldview-sociality model for religions and ideologies.

\begin{tabular}{|c|c|c|c|c|c|}
\hline Worldview-sociality & $\begin{array}{l}\text { Competitive } \\
\text { individualistic }\end{array}$ & $\begin{array}{l}\text { Competitive } \\
\text { collectivistic }\end{array}$ & $\begin{array}{l}\text { Connective } \\
\text { Individualistic }\end{array}$ & $\begin{array}{l}\text { Connective } \\
\text { Collectivistic }\end{array}$ & $\begin{array}{l}\text { No worldview } \\
\text { interdependent }\end{array}$ \\
\hline Religion & $\begin{array}{c}\text { Islam and Greek } \\
\text { individualism }\end{array}$ & Judaism and Islam & $\begin{array}{l}\text { Hinduism and } \\
\text { Confucianism }\end{array}$ & $\begin{array}{l}\text { Hinduism and } \\
\text { Confucianism }\end{array}$ & $\begin{array}{l}\text { Daoism, } \\
\text { Buddhism, } \\
\text { Christianity }\end{array}$ \\
\hline Secular economy & Capitalism & Socialism & $\begin{array}{l}\text { Reciprocal connective } \\
\text { economy (keiretsu) }\end{array}$ & $\begin{array}{l}\text { Cohesive connective } \\
\text { economy (zaibatsu) }\end{array}$ & \\
\hline Secular politics & $\begin{array}{c}\text { Liberal } \\
\text { democracy }\end{array}$ & $\begin{array}{c}\text { Ideological } \\
\text { authoritarianism }\end{array}$ & $\begin{array}{l}\text { Individualistic } \\
\text { meritocracy } \\
\text { (meritocratic } \\
\text { selection) }\end{array}$ & $\begin{array}{c}\text { Collectivistic } \\
\text { meritocracy } \\
\text { (consensual politics) }\end{array}$ & \\
\hline
\end{tabular}




\section{The Unified Interdependent Period}

The separate developments of the sacred and the secular are not suitable for the period after the Information Revolution starting in the last half of the $20^{\text {th }}$ century when information can no longer be isolated. The world becomes increasingly interdependent. It is necessary to have a unified interdependent model for the sacred and the secular. A unified model for the sacred and the secular is the trinity model of truths consisting of the unknowable and unverifiable transcendental truth, the knowable and verifiable immanent truth, and the imaginary truth, corresponding roughly to the Father, the Son, and the Holy Spirit in Christian terminology.

The transcendental truth is unknowable and unverifiable truth beyond the nature. Even science will reach the realm which is unknowable and unverifiable. It is acceptable for both science and religion to have the unknowable and unverifiable transcendental truth beyond the nature. In the sacred, such truth is the supernatural, while in the secular, such truth is simply the nameless. The sacred immanent truth is the knowable and verifiable sacred guardian-contract. The sacred guardian emerges when humans seek the help from the supernatural as the sacred guardian during difficult time, and the sacred contract emerges between the guardian and the human beneficiary to maintain social order. In the secular, the immanent truth is secular science-ideology. The transcendental truth and the immanent truth are expressed in the first chapter of Dao De Jing translated by Derek Lin.

The Dao that can be spoken is not the eternal Dao.

The name that can be named is not the eternal name.

The nameless is the origin of Heaven and Earth.

The named is the mother of myriad things.

Thus, constantly free of desire.

One observes its wonders.

Constantly filled with desire.

One observes its manifestations.

These two emerge together but differ in name.

The unity is said to be the mystery.

Mystery of mysteries, the door to all wonders.

The nameless is the transcendental truth, while the named is the immanent truth. The two truths are united as one.

The imaginary truth is essentially derived from the human imagination that provides the concept of the supernatural. Both the transcendental truth and the imaginary truth are beyond perception. The concept of the supernatural as religion is derived from the abstraction of imaginary objects as proposed by Maurice Bloch [23] who posited that such development of imagination occurred at about the time of the Upper Paleolithic Revolution. The late Homo species are good in finding repetitive patterns (similarity-difference and cause-effect) in perceived objects as the abstraction of perceived objects [24]. The abstraction of perception allows animals to solve similar problems with the same patterns. It is a powerful problem solving tool. Unlike perceived objects, the abstraction of perception is immaterial, and does not correspond to any particular perceived objects, so the abstraction of perception is the steppingstone for imaginary objects which also do not correspond to any perceived objects. The abstraction of imaginary objects is the abstraction of imagination. The abstraction of imagination is equivalent to "theory of mind" to recognize (imagine) that the others exist to think (abstract) for themselves. In other words, you imagine thinking like another person. Autistic individuals with problems in imaginative capacities are incapable of theory of mind [25] [26]. The practical purposes of imagination are to imagine you thinking like another person to detect cheatings by the person and to imagine yourself in a hypothetical situation to detect dangers in the situation. The original purposes of human imagination were practical. The sequence of the evolution of the perception is perceived objects, the abstraction of perception based on the abstraction of perceived objects, imaginary objects, and the abstraction of imagination based on the abstraction of imaginary objects.

$$
\begin{aligned}
& \text { perceived objects } \longrightarrow \text { abstraction of perception } \\
& \longrightarrow \text { imaginary objects } \longrightarrow \text { abstraction of imagination }
\end{aligned}
$$

The expansion of imaginary objects for the late Homo species involved the imaginary objects such as artificial artistic objects [27] before the Upper Paleolithic Revolution. The gigantic expansion of the abstraction of imagination involved the supernatural when the vulnerable humans turned to the supernatural for help despe- 
rately during the harsh Upper Paleolithic Period. For the supernatural as religion, the imaginary objects are the imaginary supernatural agents behind all perceived objects, and the abstraction of imagination is the supernatural as the repetitive pattern of all supernatural imaginary agents behind all perceived objects. In terms of the abstraction of imagination as theory of mind, humans recognize (imagine) that the supernatural exists to think (abstract) for oneself. During difficult time, humans turn to the supernatural as the sacred guardian for help through the human imagination as the spirit connecting the supernatural and humans.

The abstraction of imagination has been expanded rapidly to all different areas since the Upper Paleolithic Revolution. According to Maurice Bloch, imagination becomes omnipresence in human culture [23]. The abstraction of mathematical imagination is the base for natural science and engineering. The abstraction of logical imagination is the base for social science philosophy, and ideology. The abstraction of artistic imagination is the base for abstract art. None of the abstractions of imagination corresponds exactly to the abstraction of perception. The purposes of perception and the abstraction of perception are entirely for survival and reproduction here and now, not for eternal reality. The abstractions of imagination which deviates from the abstraction of perception may actually closely correspond to eternal reality as shown in natural science as the eternal reality of the physical nature which cannot be modeled by the abstraction of perception for survival and reproduction here and now.

Both the sacred guardian-contract and the secular science-ideology are derived from the human imagination for the imaginary truth. The sacred and the secular should not exclude one another. As long as there are vulnerable individuals to seek the sacred guardian, there is sacred religion consisting of the sacred guardian and the sacred community to help vulnerable individuals [28]. Individual vulnerability is the key to form social group as shown in the Group-interest Equation (Equation (3)). Individual vulnerability is omnipresent. Social group is there to overcome individual vulnerability. In the same way, religion is there to overcome individual vulnerability. Jesus said, “Come to me, all you who are weary and burdened, and I will give you rest.” (Matthew 11:28) Albert Einstein said, "Science without religion is lame, religion without science is blind.” As a result, the scared and the secular are interdependent.

The sacred and the secular can be described by the worldview-sociality model (Table 2), and a unified interdependent sacred-secular model is the trinity model of truths. Homo sapiens in majority of the time are secular. The human civilization in majority of the time has been sacred. In the developed countries, the society is increasingly secular. The sacred guardian-contract and the secular science-ideology are equally true as long as they benefit people and the earth. People in different cultures, backgrounds, experiences, and personalities have different sacred guardians-contracts and secular science-ideologies. In the peaceful world of the unified interdependent period, people understand and tolerate the diversity in the sacred, the secular, worldview, and sociality, and find ways to unify them. The summary of the trinity model of truths is in Table 3.

\section{Conclusions}

The posited religious evolution is derived from individual vulnerability, the sacred guardian-contract, the technological revolutions, and the worldview-sociality model. The worldview-sociality model consisting two worldviews (competitive and connective) and three socialities (individualistic, collectivistic, and interdependent) is derived from the Evolution Equation for the biological evolution based on self-interest, adaptation, and competition. The competitive collectivistic religions are Judaism and Islam. The competitive individualistic religions are Greek individualism and Islam. The connective religions are Hinduism and Confucianism. The interdependent religions are Buddhism, Daoism, and Christianity. The five periods of human religious evolution are 1) the eusocial secular period started by original Homo sapiens, 2) the eusocial sacred guardian-community period started from the Upper Paleolithic Revolution, 3) the sacred guardian-community-contract period started by

Table 3. The trinity model of truths.

\begin{tabular}{|c|c|c|c|}
\hline The Truths & The Transcendental Truth & The Immanent Truth & The Imaginary Truth \\
\hline Description & Unknowable and unverifiable beyond the nature & Knowable and verifiable & Imaginary beyond perception \\
\hline Christian terms & The Father & The Son & The Holy Spirit \\
\hline Sacred terms & The supernatural & The sacred guardian-contract & The spirit \\
\hline Secular terms & The nameless & The secular science-ideology & The human imagination \\
\hline
\end{tabular}


Table 4. Human religious evolution of Homo sapiens.

\begin{tabular}{|c|c|c|c|c|c|}
\hline Period & Revolution & Worldview & Sociality & Society & Sacred and secular \\
\hline Eusocial secular & $\begin{array}{l}\text { Homo } \\
\text { sapiens }\end{array}$ & None & Interdependent & $\begin{array}{c}\text { Eusocial secular } \\
\text { hunter-gather society }\end{array}$ & Secular \\
\hline $\begin{array}{c}\text { Eusocial sacred } \\
\text { guardian-community }\end{array}$ & $\begin{array}{c}\text { Upper } \\
\text { Paleolithic }\end{array}$ & None & Interdependent & $\begin{array}{c}\text { Eusocial sacred } \\
\text { hunter-gatherer society }\end{array}$ & Sacred guardian \\
\hline $\begin{array}{c}\text { Sacred } \\
\text { guardian-community-contract }\end{array}$ & Agricultural & $\begin{array}{l}\text { Competitive, } \\
\text { connective }\end{array}$ & $\begin{array}{l}\text { Individualistic, } \\
\text { collectivistic, } \\
\text { interdependent }\end{array}$ & $\begin{array}{c}\text { Sacred } \\
\text { agricultural-nomadic } \\
\text { society }\end{array}$ & $\begin{array}{c}\text { Sacred } \\
\text { guardian-contract }\end{array}$ \\
\hline Sacred-secular & Industrial & $\begin{array}{l}\text { Competitive, } \\
\text { connective }\end{array}$ & $\begin{array}{l}\text { Individualistic, } \\
\text { collectivistic, } \\
\text { interdependent }\end{array}$ & $\begin{array}{l}\text { Separate sacred-secular } \\
\text { industrial society }\end{array}$ & $\begin{array}{c}\text { Separate sacred } \\
\text { guardian-contract } \\
\text { and secular } \\
\text { science-ideology }\end{array}$ \\
\hline Unified interdependent & Information & $\begin{array}{l}\text { Competitive, } \\
\text { connective }\end{array}$ & $\begin{array}{l}\text { Individualistic, } \\
\text { collectivistic, } \\
\text { interdependent }\end{array}$ & $\begin{array}{c}\text { Unified interdependent } \\
\text { sacred-secular } \\
\text { information society }\end{array}$ & $\begin{array}{c}\text { Unified } \\
\text { interdependent } \\
\text { sacred-secular }\end{array}$ \\
\hline
\end{tabular}

the Agricultural Revolution, 4) the sacred-secular period started by the Industrial Revolution, and 5) the unified interdependent period started by the Information Revolution. a) In the eusocial secular period, the original human society was the secular interdependent society without significant religious practice. b) Facing the harsh environment during the Upper Paleolithic Period, the vulnerable humans sought the help from the supernatural as the sacred guardian, resulting in religion and the Upper Paleolithic Revolution. c) The large and complex human society started by the Agricultural Revolution transformed the simple sacred guardian into the sacred contract between the sacred guardian and the human society to maintain social order. d) Science, individualism, and pluralism in the Industrial Revolution brought back the secular, resulting in the sacred-secular period. e) The closely interacting information started by the Information Revolution starts the unified interdependent period unifying the sacred and the secular. A unified model is the trinity model of truths consisting of the unknowable and unverifiable transcendental truth beyond the nature, the knowable and verifiable immanent truth, and the imaginary truth.

The summary of human religious evolution is described in Table 4 .

\section{References}

[1] Bellah, R. (2011) Religion in Human Evolution: From the Paleolithic to the Axial Age. Harvard University Press, Cambridge. http://dx.doi.org/10.4159/harvard.9780674063099

[2] Chung, D. (2016) The Basic Principles of Kin Sociality and Eusociality: Human Evolution. Natural Science, 8, 8-19. http://dx.doi.org/10.4236/ns.2016.81002

[3] Hamilton, W. (1964) The Genetical Evolution of Social Behavior I. Journal of Theoretical Biology, 7, 1-16. http://dx.doi.org/10.1016/0022-5193(64)90038-4

[4] Hamilton, W. (1964) The Genetical Evolution of Social Behavior II. Journal of Theoretical Biology, 7, 17-52. http://dx.doi.org/10.1016/0022-5193(64)90039-6

[5] Crespi, B.J. and Douglas, Y. (1995) The Definition of Eusociality. Behavior Ecology, 6, 109-115. http://dx.doi.org/10.1093/beheco/6.1.109

[6] Wilson, E.O. (2012) The Social Conquest of the Earth. W. W. Norton \& Company, New York.

[7] Sahlins, M. (1968) Notes on the Original Affluent Society. In: Lee, R. and De Vore, I., Eds., Man the Hunter, Aldine de Gruyter, New York, 85-89.

[8] Taylor, S. (2005) The Fall: The Evidence for a Golden Age, 6000 years of Insanity and the Dawning of a New Era. O Books, Winchester.

[9] Dixson, A. and Dixson, B. (2011) Venus Figurines of the European Paleolithic: Symbols of Fertility or Attractiveness? Journal of Anthropology, 2011, Article ID: 569120. http://dx.doi.org/10.1155/2011/569120

[10] Lewis-Williams, D. (2002) The Mind in the Cave: Consciousness and the Origins of Art. Thames \& Hudson, London.

[11] Cunliffe, B. (2001) The Oxford Illustrated History of Prehistoric Europe. Oxford University Press, Oxford.

[12] Klein, R. (1995) Anatomy, Behavior, and Modern Human Origins. Journal of World Prehistory, 9, 167-198. 
http://dx.doi.org/10.1007/BF02221838

[13] Henneberg, M. (1988) Decrease of Human Skull Size in the Holocene. Human Biology, 60, 395-405.

[14] Hare, B., Wobber, V. and Wrangham, R. (2012) The Self-Domestication Hypothesis: Evolution of Bonobo Psychology Is Due to Selection against Aggression. Animal Behavior, 83, 573-585. http://dx.doi.org/10.1016/j.anbehav.2011.12.007

[15] Hood, B. (2014) The Domesticated Brain. Penguin Books Ltd, London.

[16] Higham, T. (2014) The Timing and Spatiotemporal Patterning of Neanderthal Disappearance. Nature, 512, $306-309$. http://dx.doi.org/10.1038/nature13621

[17] Kelly, R. (2000) Warless Societies and the Origins of War. University of Michigan Press, Ann Arbor.

[18] Turner, J.C. and Reynolds, K.J. (2010) The Story of Social Identity. In: Postmes, T. and Branscombe, N., Eds., Rediscovering Social Identity: Core Sources, Psychology Press, New York, 13-32.

[19] Cohen, T., Montoya, R. and Insko, C. (2006) Group Morality and Intergroup Relations: Cross-Cultural and Experimental Evidence. Personality and Social Psychology Bulletin, 32, 1559-1572. http://dx.doi.org/10.1177/0146167206291673

[20] Shultz, T., Hartshorn, M. and Kaznatcheev, A. (2009) Why Is Ethnocentrism More Common than Humanitarianism? In: Taatgen, N.A. and van Rijn, H., Eds., Proceedings of the 31st Annual Conference of the Cognitive Science Society, Cognitive Science Society, Austin, 2100-2105.

[21] Hamlin, J.K., Mahajan, N. and Wynn, K. (2013) Not Like Me = Bad: Infants Prefer Those Who Harm Dissimilar Others. Psychological Science, 24, 589-594. http://dx.doi.org/10.1177/0956797612457785

[22] Nisbett, R. (2004) The Geography of Thought: How Asians and Westerners Think Differently... and Why. Free Press, New York.

[23] Bloch, M. (2006) Why Religion Is Nothing Special but Is Central. Philosophical Transactions of the Royal Society B, 363, 2055-2061.

[24] Rand, A. (1979) Introduction to Objectivist Epistemology. New American Library, New York.

[25] Scott, F. and Baron-Cohen, S. (1996) Imagining Real and Unreal Objects: An Investigation of Imagination in Autism. Journal of Cognitive Neuroscience, 8, 400-411. http://dx.doi.org/10.1162/jocn.1996.8.4.371

[26] Angus, D., de Rosnay, M., Lunenburg, P., Terwogt, M.M. and Begeer, S. (2015) Limitations in Social Anticipation Are Independent of Imaginative and Theory of Mind Abilities in Children with Autism but Not in Typically Developing Children. Autism, 19, 604-612. http://dx.doi.org/10.1177/1362361314537911

[27] Henshilwood, C. and Marean, C. (2003) The Origin of Modern Human Behavior: Critique of the Models and Their Test Implications. Current Anthropology, 44, 627-651. http://dx.doi.org/10.1086/377665

[28] De Botton, A. (2012) Religion for Atheists: A Non-Believer’s Guide to the Uses of Religion. Hamish Hamilton, London. 